\title{
The dark-side of the outside: how extracellular heat shock proteins promote cancer
}

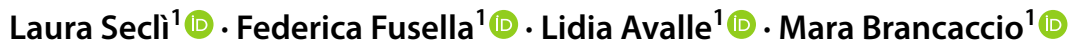

Received: 7 October 2020 / Revised: 28 December 2020 / Accepted: 15 January 2021 / Published online: 5 February 2021

(c) The Author(s) 2021

\begin{abstract}
In addition to exerting several essential house-keeping activities in the cell, heat shock proteins (HSPs) are crucial players in a well-structured molecular program activated in response to stressful challenges. Among the different activities carried out by HSPs during emergency, they reach the extracellular milieu, from where they scout the surroundings, regulate extracellular protein activity and send autocrine and paracrine signals. Cancer cells permanently experience stress conditions due to their altered equilibrium and behaviour, and constantly secrete heat shock proteins as a result. Other than supporting anti-tumour immunity, extracellular heat shock proteins (eHSPs), can also exacerbate cancer cell growth and malignancy by sustaining different cancer hallmarks. eHSPs are implicated in extracellular matrix remodelling, resistance to apoptosis, promotion of cell migration and invasion, induction of epithelial to mesenchymal transition, angiogenesis and activation of stromal cells, supporting ultimately, metastasis dissemination. A broader understanding of eHSP activity and contribution to tumour development and progression is leading to new opportunities in the diagnosis and treatment of cancer.
\end{abstract}

Keywords Extracellular · Chaperones · Heat shock proteins · Tumour microenvironment · Cancer hallmarks

\section{Introduction}

"It did not matter if this interpretation was true or false, it was a working link between imagination and reality, like love" [1].

This is how Ferruccio Ritossa described his discovery of the heat shock proteins, and at least 20 years later, this perception is still alive, considering the finding of new and unexpected roles played by these multifaceted proteins.

Heat shock proteins (HSPs) were originally identified as stress-responsive proteins required for cell survival during thermal stress, acting as molecular chaperones. Shortly afterwards, it became clear that HSPs are induced in response to

Laura Seclì and Federica Fusella have contributed equally to the article.

Laura Seclì

laura.secli@unito.it

Mara Brancaccio

mara.brancaccio@unito.it

1 Department of Molecular Biotechnology and Health Sciences, University of Torino, Turin, Italy a wider variety of insults (of physical, chemical and biological origin), preventing cell death. However, despite the name, most HSPs are ubiquitously expressed even in physiological conditions, since they are essential for housekeeping functions inside the cell [2]. Cells possess different families of chaperones with specific activities and functions, often working in cooperation to fold native proteins and assist the formation of supramolecular complexes, keep proteins in activation-competent conformations, and stabilize them during the conformational changes required for their activities. Chaperones are also required to re-fold denatured polypeptides, inhibit unfolded protein aggregation, and, when proteins are defective or irreversibly misfolded, direct them to degradation via proteasomal and autophagic pathways. To exert their functions on their substrate proteins, named clients, HSPs typically take part in complexes that contain other chaperones, co-chaperones, modulators of ATPase activity and various accessory proteins. A clear nomenclature for the HSPs and related chaperone genes was proposed in 2009 [3]; HSPs are currently classified according to their size into six major and broadly conserved families HSP100s, HSP90s, HSP70s and HSP60s, that use ATP hydrolysis to carry out their activity, HSP40s and small heat shock proteins (sHSPs), whose do not possess ATPase activity per se. 


\section{Some HSPs are secreted into the extracellular milieu}

The year was 1986 when Tytell [4] described for the first time the transfer of HSPs from glia to axon; almost at the same time, another article by Hightower and Guidon [5] showed the release of HSPs from cultured rat embryo cells underlying their uncanonical mechanism of secretion. For many years, these results did not convince the scientific community and were considered as potential artefacts caused by cell necrosis [6]. One of the issues questioning the active release of HSPs was the absence of a secretion leader signal in their sequence [7]. Finally, robust data demonstrating the active secretion of HSPs by living cells were provided and the scientific community fully accepted this evidence $[8,9]$. However, passive release from damaged or dead cells has been also observed in many cases $[8,9]$. The lack of involvement of the canonical secretory pathway in HSP secretion was clearly demonstrated using inhibitors of endoplasmic reticulum (ER)-Golgi vesicular trafficking. Like interleukin (IL) $1 \alpha / \beta$ and fibroblast growth factor (FGF), HSPs use alternative mechanisms for secretion $[10,11]$ including free release, vesicles or vesicular intermediates, derived from the autophagic membranes, endosomes and possibly secretory lysosomes [9] (Fig. 1). Even if the molecular details at the basis of eHSP secretion are not completely elucidated, what is clear is that many mechanisms could subsist and coexist for the same HSP in the same cell. For example, HSP70 secretion as free molecule is mediated by transmembrane proteins like ATP-binding cassette (ABC) transporters but could also occur via translocation through plasma membrane, as described for FGF2 [7]. Moreover, HSP70 requires the $\mathrm{ABC}$ family transporter proteins also to enter the endosomal or lysosomal vesicles, which in turn are secreted in the extracellular compartment $[7,12,13]$. Another mechanism is mediated by exosomes, where HSPs amount increases when cells are under heat-shock or other stress conditions. HSPs contained in exosomes are transferred to target cells modifying their behaviour [14]. eHSPs localized on the membrane of exosomes can also engage surface receptors and trigger intracellular signalling in an autocrine or paracrine fashion [15-20]. eHSPs localizes within the lipid bilayer of cellular plasma membranes by interacting with membrane lipids, possibly stabilizing membranes, regulating their physical properties and organizing microdomain composition [21] (Fig. 2). For example, intracellular HSP70, recognizing phosphatidylserine (PS) moieties, phospholipids that are normally present in the cytosolic side of cellular membranes, undergoes an insertion into the lipid bilayer, exposing a small region of its $\mathrm{C}$-terminus end to the extracellular environment. It has been proposed that, during the recovery condition after a stress stimulus,
Fig. 1 Pathways of unconventional Heat Shock Proteins (HSPs) secretion in the extracellular space. Lysosomes or endosomes fusion with plasma membrane leads to the release of HSPs in the extracellular space. HSPs can be captured from the cytoplasm during the formation of endosomal internal vesicles, which leads to the biogenesis of multivesicular bodies. These internal vesicles are then released as exosomes. HSPs can directly translocate from the cytoplasm across the plasma membrane facilitated or not by ATP-binding cassette $(\mathrm{ABC})$ transporters. Microvesicle shedding from the cell surface can also lead to the release of HSPs into the extracellular space

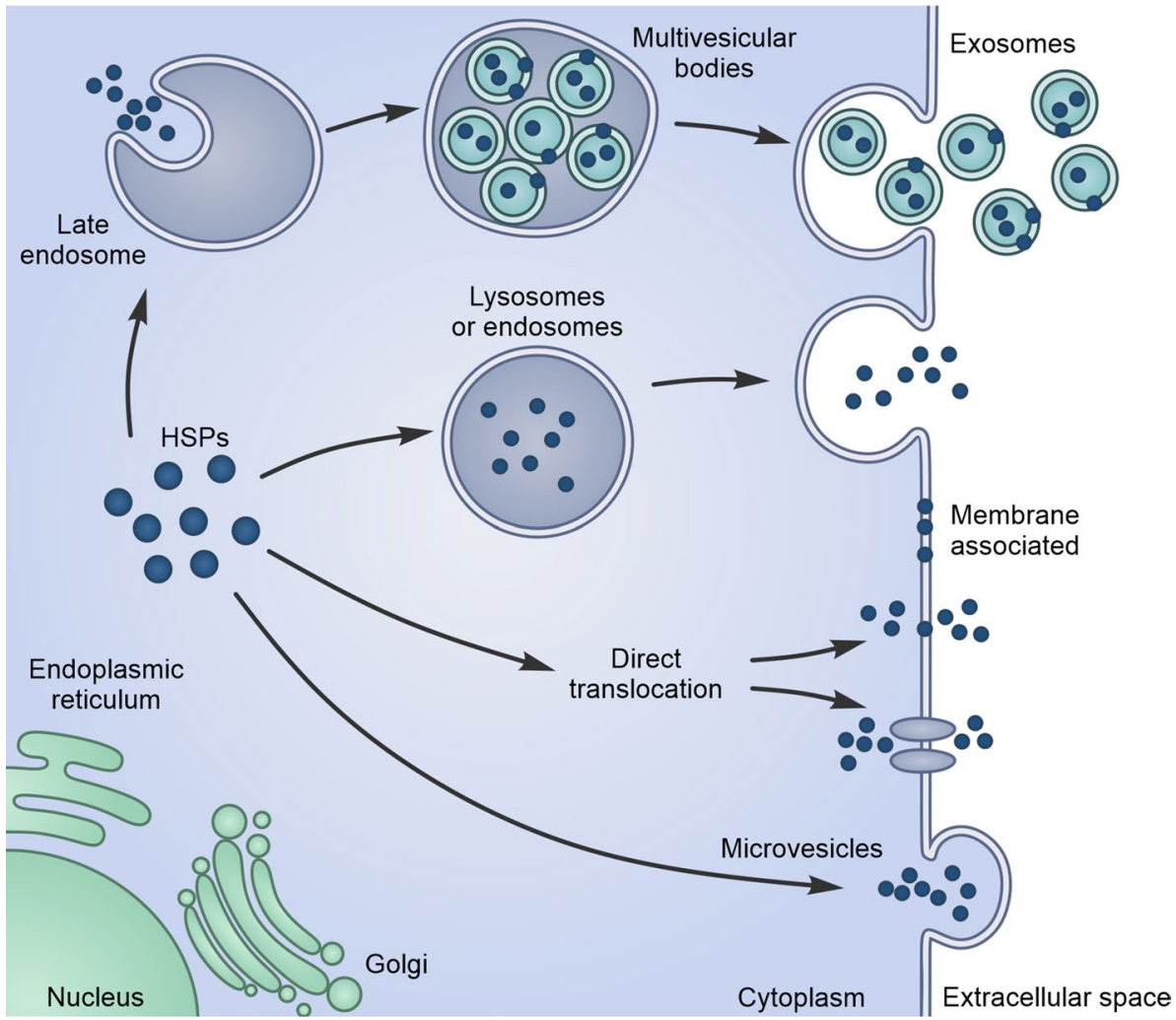




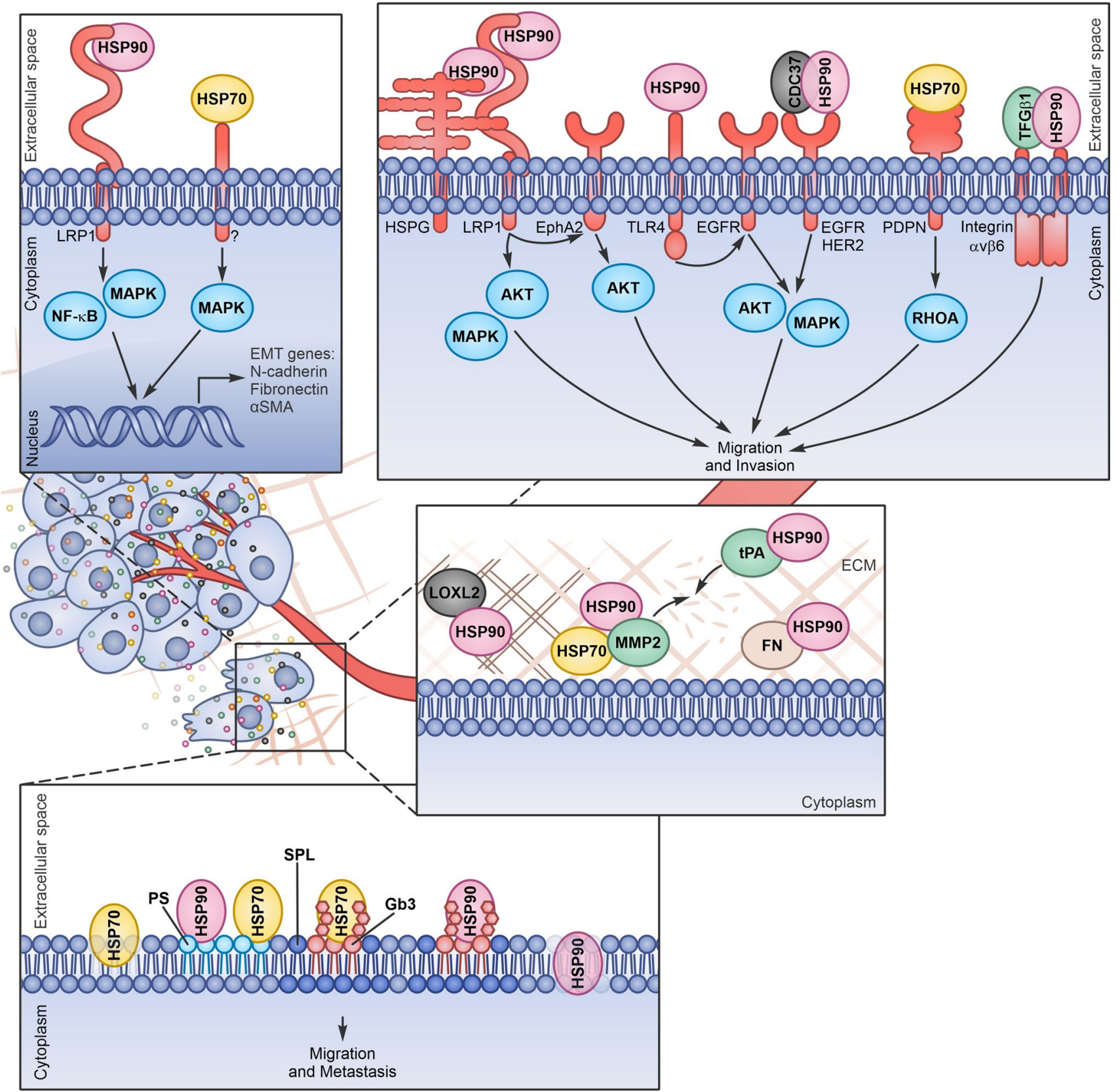

Fig. 2 Extracellular Heat Shock Proteins (eHSPs) induce extracellular matrix (ECM) remodelling, epithelial-mesenchymal transition (EMT), migration and invasion. eHSPs released by cancer cells can interact with extracellular client proteins favouring ECM remodelling and with surface receptors, triggering signal transduction inside the cells ( $H S P G$ heparan sulfate proteoglycans, $F N$ fibronectin, PDPN podoplanin)

are enriched not only in cholesterol but also in glycosphingolipids, glycosylphosphatidylinositol-anchored and acetylated proteins [21-24]. Experimental data indicate that HSP70 is exposed on the surface of tumour cells through the binding with the ceramide-derived glycosphingolipid globotriaoslyceramide (Gb3) that accumulates in lipid rafts [25]. 


\section{Extracellular HSPs and cancer}

HSPs levels have been found aberrantly high in human cancers compared to normal tissues and correlated with poor prognosis [26, 27]. HSPs overexpression in cancers is a response to the internal stress experienced by malignant cells, such as lack of proteostasis due to high levels of protein synthesis and to the presence of mutant proteins, and to stresses imposed by the hostile tumour microenvironment (TME), like hypoxia, nutrient deprivation, and acidosis [28]. Cancer growth is a complex, multistep process that requires cells to acquire some intrinsic characteristics, as genomic instability, resistance to cell death, altered metabolism and motility and to modify the TME inducing angiogenesis, inflammation and immune evasion [29, 30]. The role of intracellular chaperones and co-chaperones in sustaining transformation and cancer progression is well known, as the attitude of cancer cells to become addicted to HSP overexpression [31]. It is now widely accepted that HSPs are released by different types of cancers and are associated with their plasma membranes [32]. Several studies describe the tumour-specific immunogenicity of these released or surface-localized HSPs, a function associated with their ability to chaperone antigenic peptides and to activate anti-tumour innate immunity [33, 34]. The role of eHSPs in inhibiting inflammation and in promoting immune surveillance has been extensively investigated and recently reviewed [35-39], and therefore is not subject of debate in this review.

But, despite their tumour-alerting role, the surface and extracellular localization of HSPs may not be entirely beneficial to the host and, on the contrary, can play key functions in promoting tumour progression and metastasis formation, modulating several cancer hallmarks [38, 40-42]. Different extracellular chaperones and co-chaperones have been reported to be secreted by cancer cells; however, the majority of data demonstrating an active role of eHSPs in cancer refers to HSP90, HSP70 and HSP27.

HSP90 is the most abundantly expressed protein accounting for the $2-3 \%$ of the total proteins in normal cells and up to $7 \%$ in tumour cells [43]. HSP90 comes in two isoforms: the inducible HSP90 $\alpha$ and the constitutive HSP90 $\beta$. While HSP90 $\beta$, but not HSP90 $\alpha$, is critical for the cell viability, HSP90 $\alpha$ is mainly involved in cell responses to external stressors. Of note, cancer cells predominantly secrete the HSP90 $\alpha$ isoform [44]. Indeed, analysing the sera of patients with cancer (including esophageal squamous cell carcinoma, melanoma, lung, breast, liver, pancreas and prostate cancer), eHSP90 $\alpha$ level positively correlates with tumour progression $[45$, $46]$ as well as with the metastatic lesions in distant organs [46-48], functioning as a useful diagnostic and prognostic biomarker. eHSP90 $\alpha$ translocation in the plasma membrane of different cancer cells and its subsequent release in the medium relies on different stimulus-activated cascades as the hypoxia-inducible factor (HIF) $1 \alpha$ and the epidermal growth factor (EGF)-induced phospholipase (PLC) $\gamma 1 /$ protein kinase C (PKC) $\gamma$ signalling [49]. Moreover, eHSP90 $\alpha$ secretion in breast cancer cells depends also on protein modifications, including PKA-mediated phosphorylation [48] and acetylation [50]. The HSP70 family includes several slightly different proteins: among them, the constitutively expressed HSC70 and the stress-inducible HSP72, the HSP70 located in the mitochondria (GRP75) and GRP78, resident in the endoplasmic reticulum. Cell membrane localization of eHSP70 has been found on different cancer cell lines and on patients' tumours and metastases, but not on the normal tissues counterparts [51]. In particular, eHSP72 is described on the surface of sarcoma, lung carcinoma and pancreatic cancer cell lines [52-54]. eHSP70 has been found on the surface of cancer cells in metastatic lesions in melanoma patients, together with eHSP90 [45, 51]. Exosomes released by cancer cells expose HSP70 on their membranes, while exosomes derived by normal cells do not. This feature makes the presence of HSP70 on patients' exosomes a promising biomarker for monitoring cancer growth, relapse and appearance of metastasis, useful to guide therapeutic interventions [52, 55-58]. eHSP27, a member of the small HSPs, has been found in the sera of patients with squamous cell carcinoma of the tongue, breast, liver and ovarian cancer [59-64] and its secretion is associated with enhanced tumour growth and metastasis.

After release in the extracellular compartment or inside vesicle membranes, HSPs can chaperone and activate specific extracellular client proteins or directly interact with surface receptors, unleashing specific intracellular signals in target cells. In both cases, eHSPs have been described to promote malignancy and enhance metastasis formation.

\section{Extracellular client proteins in cancer}

Extracellular matrix (ECM) is the non-cellular constituent of tissues that provides both biochemical and structural support for the cellular component, favouring cell-cell communication, cell adhesion, and cell proliferation. In addition to water and minerals, it is composed of collagen, proteoglycans, laminin, and fibronectin secreted by resident cells. ECM is a highly dynamic structure, constantly undergoing a remodelling process, in which components are degraded and modified by different proteases. Of note, the majority of the eHSP client proteins are ECM or enzymes involved in ECM remodelling [65-69]. ECM remodelling is a hallmark of cancer progression, impacting on cell proliferation, migration, and apoptosis [70, 71]. Indeed, a common feature 
of cancer malignancies is the excessive production of collagens, which are the major components of the ECM. Collagens can act as a scaffold, facilitating migration of invading cancer cells or stromal cells. In addition, increased collagen deposition and increased fibril cross-linking is associated with major changes in biomechanical properties of tissues, contributing to stiffness, which is crucial for a tumour to displace the host tissue and grow in size [72].

Fibronectin is secreted by cells as a soluble dimer and the subsequent binding to integrin receptors, exposed on the cell surface, induces a fibronectin conformational changes that expose self-association domains and promote the formation of an insoluble matrix in the extracellular space. Increased turnover of the extracellular fibronectin matrix has been correlated with enhanced metastatic capacity of tumour cells. As collagen assembly relies on fibronectin, fibronectin network depends on collagen and together can favour migration and invasion of both cancer cells and activated fibroblasts $[70,71]$.

ECM modifying enzymes such as matrix metalloproteinases (MMPs), heparanase, cathepsins, plasminogen activator (PA) and the lysyl oxidase (LOX) family are in charge of ECM structuring and turnover and their deregulated expression in tumours, significantly contribute to cancer progression and metastasis. Of note, a number of these enzymes depend on eHSPs for their activity and stability.

MMPs are structurally related zinc metalloproteinases, present on the cell surface or secreted in the extracellular compartment. At present, more than 21 mammalian MMPs have been identified and they are historically classified according to their substrate specificity and structural similarity in collagenases, gelatinases, stromelysins and matrilysins [73]. Due to the increasing number of proteins identified, MMPs are now divided into eight groups according to their structure. The MMPs are synthesized as inactive zymogens (pro-MMPs) and their activation requires proteolytic removal of the prodomain [73]. Most of the MMPs are activated outside the cell by other activated MMPs or serine proteinases. MMP2 and MMP9 are frequently overexpressed and highly secreted in human cancers. These soluble gelatinases, whose preferential substrates include type IV collagen, elastin, vitronectin, and aggrecan, possess also non proteolytic activities, regulating signalling pathways that control cell growth, inflammation, or angiogenesis [74, 75].

The plasminogen activator is a serine protease that cleaves the inactive proenzyme plasminogen into active plasmin; a broad spectrum serine protease that is, in turn, able to degrade fibronectin, laminin, vitronectin, proteoglycans, as well as fibrin and activate latent collagenases, including MMPs. Plasminogen activation is catalysed by urokinasetype (uPA) or tissue-type (tPA) plasminogen activators, which are subjected to time- and space-dependent regulation. In particular, the role of PAs in tissue remodelling seems consistent with the finding of their overexpression in human tumours, as well as their elevated amount in the plasma of breast, prostate, head and colon cancer patients [70].

Lysyl oxidases (LOX) are secreted amine oxidases. The family includes five members (LOX and LOX-like 1-4), whose primary function is the covalent crosslinking of collagens and/or elastin in the ECM. The aberrant expression, secretion and activity of these proteins have been reported in a range of human cancers. Indeed, some LOX members (in particular LOXL2) promote tumour cell survival, regulate cell adhesion, motility and invasion, and remodel the TME. LOX- and LOXL2-mediated tumour progression is due primarily to ECM modifications but relies in part on intracellular signalling. Upregulation of LOXL2 has been observed in a number of human cancers, and its expression has been associated with cancer aggressiveness $[70,76]$.

\section{eHSP receptors in cancer}

In addition, eHSPs can directly interact with several cell surface receptors influencing cell behaviour through both autocrine and paracrine signalling [77]. The main HSPactivated receptors involved in cancer progression are Low density lipoprotein receptor-related protein 1 (LRP1), Toll Like Receptors (TLRs), the EGF receptor family (ERBB) and cluster of differentiation 40 (CD40) [78, 79].

LRP1 or CD91 protein consists of a large extracellular ligand-binding subunit non-covalently associated to a smaller subunit, containing a transmembrane domain and a short cytoplasmic tail. LRP1 is expressed in a large panel of cells, such as hepatocytes, fibroblasts, smooth muscle cells, neurons and astrocytes [80]. More than forty LRP1 ligands have been identified nowadays, including apolipoproteins, proteinases, proteinase-inhibitor complexes, bacterial toxins, viruses, the blood coagulation factor VIII, and various extracellular matrix proteins such as MMPs and uPA [81]. LRP1 is internalized in vesicles to deliver bound ligands to the endosomal/lysosomal compartment and is then recycled on the plasma membrane [82]. Beyond its ability to internalize extracellular components, LRP1 initiates and regulates many signalling pathways, as small Rho family GTPases, extracellular signal-regulated kinase (ERK), AKT and c-Jun N-terminal kinase (JNK) pathways [83-85]. Indeed, LRP1 expression is often deregulated in human cancers. LRP1 also exerts a fundamental role in cytoskeleton organization, focal adhesion disassembly and integrin $\beta 1$ maturation, regulating cell adhesion, spreading, migration and invasion. It was proposed for the first time as the receptor of several extracellular chaperones by the group of Srivastava [86] and later many other studies confirmed its role as eHSP receptor in cancer cells. 
TLR family members are type I transmembrane glycoproteins structurally characterized by the presence of a leucine-rich repeat domain in their extracellular region and a Toll/IL-1 receptor (TIR) domain in their intracellular portion, which activates common signalling pathways via TLRspecific adaptor proteins. [87, 88]. To date, ten TLRs have been identified in humans, the expression of which has been demonstrated on various innate immune cells, such as macrophages, neutrophils, and dendritic cells (DCs), as well as non-immune cells including epithelial and endothelial cells. While, TLRs 1, 2, 4, 5 and 6 are expressed on the cell surface, TLRs 3, 7, 8 and 9 are found almost entirely within endosomes [89]. Although individual TLRs recognize distinct ligands, the mechanisms of TLR activation and signal transduction are highly conserved and involve MyD88dependent and -independent pathways that, in turn, activate multiple pro-inflammatory signalling cascades including nuclear factor kappa-light-chain-enhancer of activated B cells (NF-kB), JNK/activator protein 1 (AP1), ERK and p38 $[87,88]$. The most common ligands of TLRs are the bacterial cell-surface lipopolysaccharides (LPS), lipoproteins and lipopeptides of bacterial origin, proteins such as flagellin from bacterial flagella, double-stranded RNA of viruses and the unmethylated $\mathrm{CpG}$ islands of bacterial and viral DNA. It was shown that TLRs (in particular TLR2 and 4) can be also activated by many endogenous molecules including fibrinogen, surfactant protein-A, heparin, $\beta$-defensin 2, High Mobility Group Box 1 (HMGB1) and HSPs. In particular, TLR2 and 4 have been extensively validated as eHSP receptors and some indications exist also for TLR3 (when present in plasma membrane [89]) and TLR5 [87]. TLRs may promote carcinogenesis by unleashing pro-inflammatory, anti-apopototic, proliferative and pro-fibrogenic signals on tumour cells and cells of the tumour microenvironment, as fibroblasts, immune and endothelial cells [88].

ERBB receptors are a subclass of the receptor tyrosine kinase superfamily and comprises four members: EGFR/ ERBB1, human epidermal growth factor receptor (HER)2/ ERBB2, HER3/ERBB3 and HER4/ERBB4. All members have an extracellular ligand-binding region, a single membrane-spanning region and a cytoplasmic tyrosine-kinasecontaining domain. The ERBB receptors are expressed in various tissues of epithelial, mesenchymal and neuronal origin and their ligands are members of the EGF family of growth factors. Activated ERBBs stimulate many intracellular signalling pathways including the mitogen-activated protein kinase (MAPK) and the phosphoinositide 3-kinase (PI3K)/AKT pathways. Despite extensive overlap in the molecules that are recruited to the different active receptors, different ERBBs preferentially modulate certain signalling pathways, owing to the ability of individual ERBBs to bind specific effector proteins. These receptors are implicated in the development of many types of tumours favouring proliferation, apoptosis inhibition and cancer progression [90].

CD40 is a member of the tumor necrosis factor (TNF) receptor superfamily, expressed by B cells, dendritic cells, monocytes, platelets and macrophages as well as by nonhematopoietic cells such as myofibroblasts, fibroblasts, epithelial and endothelial cells. CD40 ligand (CD40L) is a member of the TNF superfamily that binds to CD40 promoting the activation of signal transduction pathways thanks to several TRAF (TNF Receptor Associated Factor) proteins, including TRAF1, TRAF2, TRAF3, TRAF5, and TRAF6. CD40-mediated signalling pathways include the activation of NF- $\mathrm{KB}, \mathrm{MAPK}$ and signal transducer and activator of transcription (STAT) 3, favouring the generation of an acquired immune response. In particular, in cancer, CD40 can license DCs to promote anti-tumour T cell activation and re-educate macrophages, from M2 state to M1 state, leading to fibrosis degradation and tumour regression $[91,92]$.

\section{eHSPs tune cancer hallmarks}

\section{Extracellular matrix remodelling}

eHSPs regulate ECM remodelling and stiffness interacting and regulating several extracellular client proteins. eHSP90 $\alpha$ (and in some cases HSP70) has found to be crucial for the invasiveness and metastasis formation of fibrosarcoma, esophageal squamous cell carcinoma and breast cancer cells. eHSP90 $\alpha$ assists the proteolytic activation of MMP2 in conjunction with HSP70 and the co-chaperones Hop, HSP40, and p23 and protects MMP2 from inactivation, covering one of its autocatalytic cleavage site [46, 48, $65,68]$. eHSP90 $\alpha$ acetylation seems crucial to facilitate its association with MMP2 in the extracellular contest [50]. In addition, LOXL2 interacting with eHSP $90 \alpha$, reaches its functional conformation and induces migration in breast cancer cells [66]. Moreover, eHSP90 $\alpha$ is found associated with the tPA in the medium of fibrosarcoma and breast cancer cells. This interaction is essential to convert and activate plasminogen to plasmin, favouring invasion [67]. eHSP90 $\alpha$ and eHSP90 $\beta$ are found on the surface of invasive cancer cells, accumulated on the leading edge and then released in the extracellular space. Invadopodial protrusion formation is the first step in tumour invasion and eHSP localization and activity in this site probably depend on their ability to interact with specific ECM proteases that have found to be essential for the matrix degradation activity of invadopodia [49, 68, 93-95]. eHSP90 $\alpha$ and eHSP90 $\beta$ are found in a common complex with fibronectin on the surface of breast cancer cells. In particular, eHSP90 $\beta$ more than eHSP90 $\alpha$ binds to fibronectin, favouring its stability and protecting it from degradation, thus participating in its assembly and 
turnover. eHSP90 maintains the stability of fibronectin, and when the chaperone is inhibited, fibronectin is internalised and degraded in lysosomes in breast cancer cells. However, despite the observed interaction between eHSP90 $\beta$ and fibronectin, it is also possible that fibronectin assembly or turnover relies on the indirect activity of eHSP90 clients. In addition, fibronectin and eHSP90 have been found to co-localize in a common complex with LRP1 on the surface of breast cancer cells. After the inhibition of HSP90, LRP1 is the putative receptor that mediates the clearance of fibronectin, but the exact mechanism remains to be elucidated. Indeed, it has been previously reported that LRP1 is able to mediate fibronectin internalization and degradation following its accumulation on fibroblasts surface. It is also possible that fibronectin internalization mediated by LRP1 is the result of specific signalling activated by eHSP90. Indeed, AKT and NF- $\kappa$ B activation (eHSP-LRP1 mediated signalling pathways) has been reported to be involved in fibronectin turnover $[69,96,97]$.

\section{Epithelial-mesenchymal transition}

The epithelial-mesenchymal transition (EMT) process is a crucial cancer hallmark that involves the disruption of cell-cell adhesion and cellular polarity, remodelling of the cytoskeleton, and changes in cell-matrix adhesion, improving migratory and invasive properties. Cytokines, growth factors and eHSPs secreted in the TME, by interacting with cancer cell plasma membrane receptors, may induce intracellular signalling pathways that favour EMT [98]. In prostate cancer cells, eHSP90 binds to LRP1 and promotes ERK signalling, leading to the impairment of E-cadherin function, the loss of junctional integrity and the induction of EMT $[99,100]$. eHSP90 is found to upregulate a cohort of stemassociated markers in prostate cancer cells, promoting selfrenewal and stemness associated with metastatic propensity [101]. In colorectal cancer (CRC) cells, eHSP90 $\alpha$ through LRP1, increases the levels of phosphorylated I $\mathrm{B}$ kinase (IKK) $\alpha / \beta$ and NF- $\kappa B$ and induces the expression of TCF12, a class I member of the helix-loop-helix protein family preferentially overexpressed in CRC patients with cancer metastasis. TCF12 is responsible for eHSP90 $\alpha$-dependent fibronectin expression and the repression of E-cadherin, connexin-26, connexin-43, associated with the EMT program [102]. In liver cancer cells, eHSP70, activating p38/ MAPK signalling pathway through an unknown receptor, causes E-cadherin reduction and alpha smooth muscle actin ( $\alpha$ SMA) overexpression favouring EMT, migration and invasion [103]. An alternative mechanism by which eHSPs may induce EMT in breast cancer relies on the ability of the eHSP client proteins MMP2 and MMP9 to proteolytically cleave and activate latent transforming growth factor (TGF) $\beta[104]$.

\section{Resistance to apoptosis}

In several pathological situations, including cancer, different stimuli can induce eHSP secretion in the extracellular milieu, where these chaperones support the response to the stress insult protecting cells from apoptosis [6]. In particular, eHSP90 once secreted under hypoxia, induces the activation of AKT pathway, through the binding to LRP1 receptor, and seems essential to protect breast cancer cells from hypoxiatriggered death [105]. In line with this, in glioblastoma (GBM) cells, hypoxia not only amplifies eHSP90 $\alpha$ secretion and its signalling, but also enhances LRP1 expression resulting in a positive loop that fuels cancer survival and progression [106]. Moreover, eHSP70 localization on the surface of colon carcinoma cells increases after radiotherapy and is associated with cell survival [107]. In a hepatocarcinoma model, eHSP72 binding to TLR2 and TLR4, promotes apoptotic resistance to chemotherapy and induces proliferation. In this study eHSP72, inducing the release of HMGB1 from cancer cells, favours also a long-lasting effect of TLR4 signalling, supporting tumour growth [108]. eHSP27 is also able to induce resistance to apoptosis. Once released from tongue cancer cells following chemotherapy, eHSP27 binds to TLR5 and triggers NF- $\mathrm{KB}$ signalling to enhance chemoresistance and promote cancer progression both in vitro and in vivo. In addition, the treatment with neutralizing antibodies against HSP27 and HSP70 sensitizes cancer cells, respectively to chemotherapy and radiotherapy $[59,107]$.

\section{Migration and invasion}

HSP $90 \alpha$, by binding to LRP1 and activating ERK and AKT pathways, induce migration and invasion in breast cancer cells [43]. In GBM, the eHSP90 $\alpha / L R P 1$ signalling is required to sustain AKT activation and the AKT-dependent phosphorylation of EphA2 (S897), a tyrosine kinase receptor that is overexpressed in the majority of GBM. EphA2 functions as an LRP1 co-receptor and its phosphorylation on S897 is crucial for its interaction with LRP1. The signalling facilitates lamellipodia formation, supporting GBM cell motility and invasion [106].

eHSP90, together with its co-chaperone CDC37, also interacts with the family of ERBB receptors, including EGFR or HER2, to promote cancer cell motility and invasion. The binding of eHSP90 to HER2 induces its heterodimerization with HER3, which in turn activates the MAPK and PI3K-AKT pathways, leading to actin rearrangement necessary for cell motility. eHSP90-dependent cancer cell migration is impaired by a monoclonal antibody, $\mathrm{mAb}$ 4C5, able to disrupt the interaction between $\mathrm{CDC} 37$ and HSP90 and CDC37 and ERBB [109, 110]. mAb 4C5 has been proved effective also in inhibiting invasion and metastasis dissemination in a preclinical model of melanoma 
[111]. eHSP90 $\alpha$ has also been described to transactivate EGFR, another member of ERBB family, favouring GBM cell migration. More specifically, eHSP90 $\alpha$ triggers TLR4, which in turn, leads to the phosphorylation and activation of EGFR in a PKC8/proto-oncogene tyrosine-protein kinase (c-Src)-dependent manner, favouring calcium mobilization and ATP release, events known to be associated with cell migration [112]. Aside from eHSP90 $\alpha$, there are also some reports that describe a pro-tumorigenic role of eHSP90 $\beta$ on primary colon adenocarcinoma cells and on their lymph node metastasis-derived counterpart. In this context, eHSP90 $\beta$ binds to TGF $\beta 1$ forming a complex that, instead of binding TGF $\beta 1$ canonical receptors to activate the $S m a d 2 / 3$ signalling pathway, engages the integrin $\alpha v \beta 6$ and promotes cancer cell invasion and metastasis through a pathway still undetermined [113].

In hepatocellular carcinoma and lung cancer cells, HSP70 promotes cancer progression by binding to TLR 2 and to the receptor for advanced glycation end products (RAGE) and inducing MyD88-dependent and -independent NF- $\mathrm{KB}$ activation and pro-inflammatory gene transcription [108, 114]. GRP75, the member of the HSP70 family predominantly localized in the mitochondria, is also secreted by cancer cells. In particular, GRP75 and podoplanin, a mucin-type transmembrane sialoglycoprotein, are able to regulate the activities of Rho, ezrin, and other proteins linked to the actin cytoskeleton, co-localize on the surface of cells derived from oral SCC patient specimens, and together regulate adhesion and matrix remodelling [115].

\section{Angiogenesis}

Angiogenesis, the process whereby new blood vessels develop from a pre-existing vascular network, is essential for normal organs, as well as for tumours, to establish a blood supply that satisfies their demand for oxygen and nutrients and accomplishes other metabolic functions. Hypoxia is a key driver of tumour angiogenesis and hypoxic cancer cells secrete vascular endothelial growth factor A (VEGFA), which initiates tumour angiogenesis binding to VEGF receptor 2 (VEGFR2) expressed on the endothelial cells of neighbouring blood vessels. In addition to VEGFA, others factors participate in this process including FGF $\alpha$ and $\beta$, platelet-derived growth factor (PDGF), TNF $\alpha$, Angiopoietin1, MMPs, PA, TGF $\alpha$ and different interleukins as IL-1, IL-6 and IL-8. VEGFA, with the help of these proangiogenic molecules, induces the motility of endothelial cells and the remodelling of surrounding extracellular matrix leading to a tumour vascular network that is actively growing and infiltrative [116]. Extracellular chaperones, secreted not only by cancer cells but also by endothelial cells, may modulate angiogenesis (Fig. 3). Indeed, eHSP90 $\alpha$, once secreted in the medium, stabilizes MMP2 and favours the transmigration and tube formation of endothelial cells in vitro and in vivo. In a melanoma mouse model, blocking with neutralizing antibodies HSP90 $\alpha$, but not HSP90 $\beta$, leads to a dose-dependent decrease in MMP2 activity, blood vessel density and tumour growth [117]. GRP78, the ER member of the HSP70 family, has been found secreted by colorectal and prostate carcinoma cells resistant to the antineoplastic agent bortezomib, a proteasome inhibitor with antiangiogenic activity. eGRP78 potently inhibits the pro-apoptotic activity of bortezomib on endothelial cells inducing the ERK/AKT pro-survival pathways and sustains angiogenesis [118]. eHSP27 was shown to promote angiogenesis through TLR3-dependent calcium entry and NF- $\kappa \mathrm{B}$ activation in endothelial cells, which induce VEGF and IL-8 secretion. These factors produce autocrine and paracrine VEGFR2 activation, causing cell migration and tubulogenesis. In vivo experiments demonstrated that the depletion of HSP27 decreases vascularization and growth of breast and colon cancer cells in mouse and rat animal models and that the treatment with eHSP27 completely reverse this effect [119], highlighting a crucial role for eHSP27 in angiogenesis and cancer cell survival.

\section{Stromal cell activation}

Fibroblasts, under normal condition, are devoted to tissue ECM maintenance. Once activated in the tumour microenvironment (mainly through TGF $\beta$ ), fibroblasts change their structure and function, acquiring the phenotype of cancerassociated fibroblasts (CAFs). CAFs can produce cytokines and factors that stimulate tumour cells proliferation, migration and invasion and tumour immunosuppression, facilitating the invasive potential of cancer cells. Different reports suggest that eHSPs released by both cancer and stroma cells can modulate and activate fibroblasts, favouring cancer progression (Fig. 3). eHSP90 $\alpha$ is observed to promote prostate fibroblast cell motility and to upregulate markers associated with a CAF-like phenotype, such as vimentin, $\alpha$ SMA, fibroblast activation factor (FAP) and tenascin C. eHSP90 $\alpha$, likely through LRP1 and the activation of NF- $\mathrm{\kappa B}$, induces fibroblasts to secrete inflammatory mediators as IL-6 and IL-8 in prostate cancer [120]. It has also been observed that the eHSP90 $\alpha$ located on the external surface of breast cancer cell exosomes, induces fibroblast invasion that can be inhibited by treating cells with an eHSP90 $\alpha$ blocking antibody [19].

Macrophages are important players in innate immunity and can polarize in M1 or M2 phenotypes depending on microenvironmental stimuli, such as cytokines, enzymes, and cell surface markers. M1 macrophages are involved in antitumor immunity and inflammatory responses characterized by the production of pro-inflammatory cytokines such as IL-6, IL-12, and TNF $\alpha$. In contrast, the M2 phenotype is 


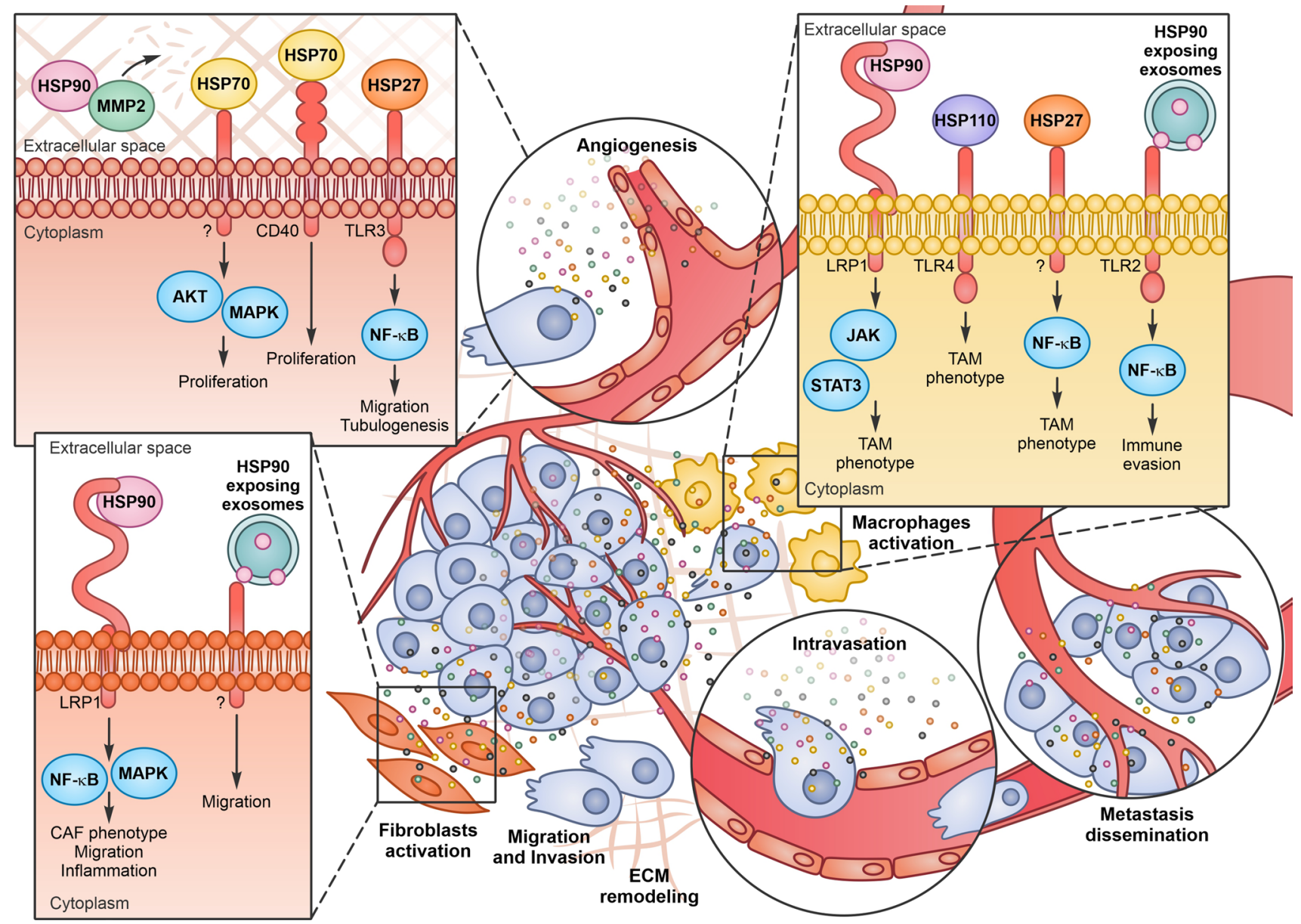

Fig. 3 Extracellular Heat Shock Proteins (eHSPs) activity in the tumor microenvironment (TME). eHSPs can interact with different receptors on endothelial cells and induce angiogenesis, on fibroblasts and on macrophages and, activate them in cancer-associated fibro-

anti-inflammatory and pro-tumorigenic, and is characterized by the production of other types of cytokines such as IL-10 and TGF $\beta$. Cancer cells recruit macrophages at the tumour site and activate them in tumour associated macrophages (TAM), that acquire a phenotype similar to M2 macrophages in the advanced stages of cancer progression. TAMs generate an immunosuppressive microenvironment and facilitate processes such as growth, angiogenesis and metastasis, producing cytokines, chemokines, and proteases. In pancreatic cancer cells, TAM express and secrete eHSP90 $\alpha$ that binds to LRP1 and activates the Janus kinase (JAK) 2-STAT3 pathway, leading to cancer progression [121]. In lung cancer patients, a strong correlation was observed also between the serum concentration of eHSP70 and the percentage of M2 polarized macrophages [122]. HSP110, which is HSP70related chaperone [3], activates stromal macrophages and is present in the serum of patients with colorectal cancer. Once secreted by colorectal cell lines, binding of HSP110 to TLR4 induces macrophages to polarize toward an M2 phenotype, blasts (CAFs) and tumor-associated macrophages (TAMs) respectively. As a final result, eHSPs induce metastasis dissemination fuelling cancer progression

while HSP110 immunodepletion, reverts this effect [123]. eHSP27, released by cancer cells in the TME, induces monocytes to express different cytokines, as IL-10, IL-6, and proangiogenic factors, as prostaglandin E2, VEGFA, IL-8, IL-1 $\beta$, and TNF $\alpha$. eHSP27 also promotes the expression and release of monocyte chemotactic protein-1 (MCP1), a potent chemotactic signal for monocytes. eHSP27 may also mediate the differentiation of circulating monocytes into TAM-like macrophages with immunosuppressive and proangiogenic phenotypes [124]. eHSP90 $\alpha$ exposed on the surface of tumour released autophagosomes can induce TLR2-MyD88-NF- $\mathrm{KB}$ signalling cascade and stimulate $\mathrm{CD} 4{ }^{+} \mathrm{T}$ cells to produce IL- 6 that functions in an autocrine manner to promote the production of IL-10 and IL-21, which create a favourable environment to facilitate tumour growth and metastasis in a melanoma mouse model [125] (Fig. 3).

Myeloid-derived suppressor cells (MDSCs) are an immature myeloid cell population that expands in subjects affected by cancer and inhibits $\mathrm{T}$ cell-mediated anti-tumor immunity. 
HSP72 exposed on tumor-derived exosomes binds to TLR2 on MDSCs and triggers STAT3 signalling, promoting IL6 expression and immunosuppressive activity [55]. Of note, a peptide aptamer able to interact with HSP72 [126] inhibits MDSC activation and tumor growth and robustly potentiates chemotherapy efficacy in cancer mouse models [57].

Even if it is not part of the topic covered by the review, it is worth mentioning that HSPs exposed on tumor-derived exosomes may also induce anti-tumor immunity, for instance by recruiting and activating natural killer cells $[14,17]$.

\section{Conclusions and future directions}

Intracellular chaperones are essential in eliciting the initiation, the development, and the recurrence of cancer, making their overexpression and cell addiction critical requisites in cancer evolution [127]. A number of experimental data point to an equally important role of extracellular HSPs in promoting and sustaining different hallmarks of cancer. eHSPs are actively secreted by cancer cells and by other cell populations in the tumour microenvironment in response to stressful conditions. Once released, eHSPs interact both with extracellular clients and with membrane receptors and tune the behaviour of cancer cells, endothelial cells, fibroblasts and macrophages, orchestrating a complex interaction network, ultimately fuelling cancer growth, migration, invasion, angiogenesis and immune escape.

The targeting of HSPs may represent an attractive strategy in cancer treatment. Unfortunately, HSPs inhibition may seriously impacts on normal cell homeostasis, causing important side effects. Indeed, despite the big effort in testing HSPs inhibitors in cancer pre-clinical models, none of them have yet been approved by the FDA for the treatment of cancer patients. This is due to the severe toxicities and, except for HSP90 inhibitors, for the lack of convincing anticancer activity because of compensatory changes in other HSPs [27]. Instead, the possibility to block extracellular chaperones may represent an attractive alternative. Treatments with eHSP cell-impermeable chemical inhibitors (like geldanamicyn beads, the geldanamicyn derivative DMAGN-oxide, the ganetespib derivative STA-12-7191) [66-68, 128] or with monoclonal antibodies blocking eHSPs [44, $48-50,67,111]$, were able to impair cancer cell invasion and metastasis dissemination in tumour pre-clinical models, without any effects of systemic toxicity.

Moreover, even if the eHSP pro-tumorigenic role has been widely demonstrated, some caution is needed; eHSPs have been first studied for their ability to facilitate antigen presentation, stimulating anti-cancer immunity and inducing tumour regression $[41,129,130]$. The ideal situation would be to uncouple pro- and anti-tumorigenic effects of extracellular chaperones and selectively inhibit their pathological activity. The growing interest in the field and the increasing amount of data regarding extracellular chaperone function and behaviour is depicting a complex scenario in which specific extracellular co-chaperones may drive eHSP functions, allowing to hypothesize that a selective inhibition is feasible.

Acknowledgements We thank Federico Patella for English corrections on the manuscript.

Author contributions LS, FF, LA and MB had the idea for the article. LS performed the literature search and wrote the manuscript. FF, LA and $\mathrm{MB}$ critically revised the work.

Funding Open Access funding provided by Università degli Studi di Torino. This work is supported by Digital Technology For Lung Cancer Treatment (DEFLeCT) to M.B. LS is supported by two-year fellowship "Federica Cipolat Mis" id. 24216, from Associazione Italiana per la Ricerca sul Cancro (AIRC).

\section{Compliance with ethical standards}

Conflict of interest The authors declare that they have no conflict of interest.

Open Access This article is licensed under a Creative Commons Attribution 4.0 International License, which permits use, sharing, adaptation, distribution and reproduction in any medium or format, as long as you give appropriate credit to the original author(s) and the source, provide a link to the Creative Commons licence, and indicate if changes were made. The images or other third party material in this article are included in the article's Creative Commons licence, unless indicated otherwise in a credit line to the material. If material is not included in the article's Creative Commons licence and your intended use is not permitted by statutory regulation or exceeds the permitted use, you will need to obtain permission directly from the copyright holder. To view a copy of this licence, visit http://creativecommons.org/licenses/by/4.0/.

\section{References}

1. Ritossa F (1996) Discovery of the heat shock response. Cell Stress Chaperones 1(2):97-98. https://doi.org/10.1379/14661268(1996)001\%3c0097:dothsr\%3e2.3.co;2

2. Richter K, Haslbeck M, Buchner J (2010) The heat shock response: life on the verge of death. Mol Cell 40(2):253-266. https://doi.org/10.1016/j.molcel.2010.10.006

3. Kampinga HH, Hageman J, Vos MJ, Kubota H, Tanguay RM, Bruford EA, Cheetham ME, Chen B, Hightower LE (2009) Guidelines for the nomenclature of the human heat shock proteins. Cell Stress Chaperones 14(1):105-111. https://doi. org/10.1007/s12192-008-0068-7

4. Tytell M, Greenberg SG, Lasek RJ (1986) Heat shock-like protein is transferred from glia to axon. Brain Res 363(1):161-164. https ://doi.org/10.1016/0006-8993(86)90671-2

5. Hightower LE, Guidon PT Jr (1989) Selective release from cultured mammalian cells of heat-shock (stress) proteins that resemble glia-axon transfer proteins. J Cell Physiol 138(2):257-266. https://doi.org/10.1002/jcp.1041380206

6. De Maio A, Vazquez D (2013) Extracellular heat shock proteins: a new location, a new function. Shock 40(4):239-246. https://doi. org/10.1097/SHK.0b013e3182a185ab 
7. Mambula SS, Stevenson MA, Ogawa K, Calderwood SK (2007) Mechanisms for Hsp70 secretion: crossing membranes without a leader. Methods 43(3):168-175. https://doi.org/10.1016/j.ymeth 2007.06.009

8. Basu S, Binder RJ, Suto R, Anderson KM, Srivastava PK (2000) Necrotic but not apoptotic cell death releases heat shock proteins, which deliver a partial maturation signal to dendritic cells and activate the NF-kappa B pathway. Int Immunol 12(11):15391546. https://doi.org/10.1093/intimm/12.11.1539

9. Santos TG, Martins VR, Hajj GNM (2017) Unconventional secretion of heat shock proteins in cancer. Int J Mol Sci. https:// doi.org/10.3390/ijms18050946

10. Rabouille C (2017) Pathways of unconventional protein secretion. Trends Cell Biol 27(3):230-240. https://doi.org/10.1016/j. tcb.2016.11.007

11. Eder C (2009) Mechanisms of interleukin-1beta release. Immunobiology 214(7):543-553. https://doi.org/10.1016/j.imbio .2008 .11 .007

12. Mambula SS, Calderwood SK (2006) Heat shock protein 70 is secreted from tumor cells by a nonclassical pathway involving lysosomal endosomes. J Immunol 177(11):7849-7857. https:// doi.org/10.4049/jimmunol.177.11.7849

13. Vega VL, Rodriguez-Silva M, Frey T, Gehrmann M, Diaz JC, Steinem C, Multhoff G, Arispe N, De Maio A (2008) Hsp70 translocates into the plasma membrane after stress and is released into the extracellular environment in a membrane-associated form that activates macrophages. J Immunol 180(6):4299-4307. https://doi.org/10.4049/jimmu nol.180.6.4299

14. Albakova Z, Siam MKS, Sacitharan PK, Ziganshin RH, Ryazantsev DY, Sapozhnikov AM (2020) Extracellular heat shock proteins and cancer: new perspectives. Transl Oncol 14(2):100995. https://doi.org/10.1016/j.tranon.2020.100995

15. Clayton A, Turkes A, Navabi H, Mason MD, Tabi Z (2005) Induction of heat shock proteins in B-cell exosomes. J Cell Sci 118(Pt 16):3631-3638. https://doi.org/10.1242/jcs.02494

16. Lancaster GI, Febbraio MA (2005) Exosome-dependent trafficking of HSP70: a novel secretory pathway for cellular stress proteins. J Biol Chem 280(24):23349-23355. https://doi. org/10.1074/jbc.M502017200

17. Gastpar R, Gehrmann M, Bausero MA, Asea A, Gross C, Schroeder JA, Multhoff G (2005) Heat shock protein 70 surfacepositive tumor exosomes stimulate migratory and cytolytic activity of natural killer cells. Can Res 65(12):5238-5247. https://doi. org/10.1158/0008-5472.CAN-04-3804

18. Takeuchi T, Suzuki M, Fujikake N, Popiel HA, Kikuchi H, Futaki S, Wada K, Nagai Y (2015) Intercellular chaperone transmission via exosomes contributes to maintenance of protein homeostasis at the organismal level. Proc Natl Acad Sci USA 112(19):E24972506. https://doi.org/10.1073/pnas.1412651112

19. Tang X, Chang C, Guo J, Lincoln V, Liang C, Chen M, Woodley DT, Li W (2019) Tumour-secreted hsp90alpha on external surface of exosomes mediates tumour-stromal cell communication via autocrine and paracrine mechanisms. Sci Rep 9(1):15108. https://doi.org/10.1038/s41598-019-51704-w

20. Reddy VS, Madala SK, Trinath J, Reddy GB (2018) Extracellular small heat shock proteins: exosomal biogenesis and function. Cell Stress Chaperones 23(3):441-454. https://doi.org/10.1007/ s12192-017-0856-Z

21. Horvath I, Multhoff G, Sonnleitner A, Vigh L (2008) Membrane-associated stress proteins: more than simply chaperones. Biochem Biophys Acta 1778(7-8):1653-1664. https://doi. org/10.1016/j.bbamem.2008.02.012

22. Triantafilou M, Miyake K, Golenbock DT, Triantafilou K (2002) Mediators of innate immune recognition of bacteria concentrate in lipid rafts and facilitate lipopolysaccharide-induced cell activation. J Cell Sci 115(Pt 12):2603-2611

23. Broquet AH, Thomas G, Masliah J, Trugnan G, Bachelet M (2003) Expression of the molecular chaperone Hsp70 in detergent-resistant microdomains correlates with its membrane delivery and release. J Biol Chem 278(24):21601-21606. https://doi. org/10.1074/jbc.M302326200

24. Arispe N, Doh M, Simakova O, Kurganov B, De Maio A (2004) Hsc70 and Hsp70 interact with phosphatidylserine on the surface of PC12 cells resulting in a decrease of viability. FASEB J 18(14):1636-1645. https://doi.org/10.1096/fj.04-2088com

25. Gehrmann M, Liebisch G, Schmitz G, Anderson R, Steinem C, De Maio A, Pockley G, Multhoff G (2008) Tumor-specific Hsp70 plasma membrane localization is enabled by the glycosphingolipid Gb3. PLoS ONE 3(4):e1925. https://doi.org/10.1371/ journal.pone.0001925

26. Ciocca DR, Calderwood SK (2005) Heat shock proteins in cancer: diagnostic, prognostic, predictive, and treatment implications. Cell Stress Chaperones 10(2):86-103

27. Wu J, Liu T, Rios Z, Mei Q, Lin X, Cao S (2017) Heat shock proteins and cancer. Trends Pharmacol Sci 38(3):226-256. https ://doi.org/10.1016/j.tips.2016.11.009

28. Ciocca DR, Arrigo AP, Calderwood SK (2013) Heat shock proteins and heat shock factor 1 in carcinogenesis and tumor development: an update. Arch Toxicol 87(1):19-48. https://doi. org/10.1007/s00204-012-0918-z

29. Welch DR, Hurst DR (2019) Defining the hallmarks of metastasis. Can Res 79(12):3011-3027. https://doi.org/10.1158/00085472.CAN-19-0458

30. Hanahan D, Weinberg RA (2011) Hallmarks of cancer: the next generation. Cell 144(5):646-674. https://doi.org/10.1016/j. cell.2011.02.013

31. Xu W, Neckers L (2007) Targeting the molecular chaperone heat shock protein 90 provides a multifaceted effect on diverse cell signaling pathways of cancer cells. Clin Cancer Res 13(6):16251629. https://doi.org/10.1158/1078-0432.CCR-06-2966

32. Shevtsov M, Balogi Z, Khachatryan W, Gao H, Vigh L, Multhoff G (2020) Membrane-associated heat shock proteins in oncology: from basic research to new theranostic targets. Cells. https://doi. org/10.3390/cells9051263

33. Udono H, Srivastava PK (1994) Comparison of tumor-specific immunogenicities of stress-induced proteins gp96, hsp90, and hsp70. J Immunol 152(11):5398-5403

34. Suto R, Srivastava PK (1995) A mechanism for the specific immunogenicity of heat shock protein-chaperoned peptides. Science 269(5230):1585-1588. https://doi.org/10.1126/scien ce. 7545313

35. Pockley AG, Henderson B (2018) Extracellular cell stress (heat shock) proteins-immune responses and disease: an overview. Philos Trans R Soci Lond Ser B Biol Sci. https://doi.org/10.1098/ rstb.2016.0522

36. Tukaj S (2020) Heat shock protein 70 as a double agent acting inside and outside the cell: insights into autoimmunity. Int J Mol Sci. https://doi.org/10.3390/ijms21155298

37. van Eden W, Jansen MAA, Ludwig I, van Kooten P, van der Zee $R$, Broere $F$ (2017) The enigma of heat shock proteins in immune tolerance. Front Immunol 8:1599. https://doi.org/10.3389/fimmu .2017.01599

38. Taha EA, Ono K, Eguchi T (2019) Roles of extracellular HSPs as biomarkers in immune surveillance and immune evasion. Int J Mol Sci. https://doi.org/10.3390/ijms20184588

39. Dukay B, Csoboz B, Toth ME (2019) Heat-shock proteins in neuroinflammation. Front Pharmacol 10:920. https://doi. org/10.3389/fphar.2019.00920

40. Multhoff G, Pockley AG, Streffer C, Gaipl US (2012) Dual role of heat shock proteins (HSPs) in anti-tumor immunity. Curr Mol 
Med 12(9):1174-1182. https://doi.org/10.2174/1566524128 03306666

41. Calderwood SK, Gong J, Murshid A (2016) Extracellular HSPs: the complicated roles of extracellular HSPs in immunity. Front Immunol 7:159. https://doi.org/10.3389/fimmu.2016.00159

42. Graner MW (2016) HSP90 and immune modulation in cancer. Adv Cancer Res 129:191-224. https://doi.org/10.1016/ bs.acr.2015.10.001

43. Sahu D, Zhao Z, Tsen F, Cheng CF, Park R, Situ AJ, Dai J, Eginli A, Shams S, Chen M, Ulmer TS, Conti P, Woodley DT, Li W (2012) A potentially common peptide target in secreted heat shock protein-90alpha for hypoxia-inducible factor-1alphapositive tumors. Mol Biol Cell 23(4):602-613. https://doi. org/10.1091/mbc.E11-06-0575

44. Zou M, Bhatia A, Dong H, Jayaprakash P, Guo J, Sahu D, Hou Y, Tsen F, Tong C, O'Brien K, Situ AJ, Schmidt T, Chen M, Ying Q, Ulmer TS, Woodley DT, Li W (2017) Evolutionarily conserved dual lysine motif determines the non-chaperone function of secreted Hsp90alpha in tumour progression. Oncogene 36(15):2160-2171. https://doi.org/10.1038/onc.2016.375

45. Becker B, Multhoff G, Farkas B, Wild PJ, Landthaler M, Stolz W, Vogt T (2004) Induction of Hsp90 protein expression in malignant melanomas and melanoma metastases. Exp Dermatol 13(1):27-32. https://doi.org/10.1111/j.0906-6705.2004.00114.x

46. Wang X, An D, Wang X, Liu X, Li B (2019) Extracellular Hsp90alpha clinically correlates with tumor malignancy and promotes migration and invasion in esophageal squamous cell carcinoma. Onco Targets Ther 12:1119-1128. https://doi.org/10.2147/ OTT.S195529

47. Shi Y, Liu X, Lou J, Han X, Zhang L, Wang Q, Li B, Dong M, Zhang Y (2014) Plasma levels of heat shock protein 90 alpha associated with lung cancer development and treatment responses. Clin cancer Res 20(23):6016-6022. https://doi. org/10.1158/1078-0432.CCR-14-0174

48. Wang X, Song X, Zhuo W, Fu Y, Shi H, Liang Y, Tong M, Chang G, Luo Y (2009) The regulatory mechanism of Hsp90alpha secretion and its function in tumor malignancy. Proc Natl Acad Sci USA 106(50):21288-21293. https://doi.org/10.1073/ pnas.0908151106

49. Yang J, Song X, Chen Y, Lu XA, Fu Y, Luo Y (2014) PLCgamma1-PKCgamma signaling-mediated Hsp90alpha plasma membrane translocation facilitates tumor metastasis. Traffic 15(8):861-878. https://doi.org/10.1111/tra.12179

50. Yang Y, Rao R, Shen J, Tang Y, Fiskus W, Nechtman J, Atadja P, Bhalla K (2008) Role of acetylation and extracellular location of heat shock protein 90alpha in tumor cell invasion. Can Res 68(12):4833-4842. https://doi.org/10.1158/0008-5472. CAN-08-0644

51. Farkas B, Hantschel M, Magyarlaki M, Becker B, Scherer K, Landthaler M, Pfister K, Gehrmann M, Gross C, Mackensen A, Multhoff G (2003) Heat shock protein 70 membrane expression and melanoma-associated marker phenotype in primary and metastatic melanoma. Melanoma Res 13(2):147-152. https:// doi.org/10.1097/00008390-200304000-00006

52. Multhoff G, Botzler C, Wiesnet M, Muller E, Meier T, Wilmanns W, Issels RD (1995) A stress-inducible 72-kDa heat-shock protein (HSP72) is expressed on the surface of human tumor cells, but not on normal cells. Int J Cancer 61(2):272-279. https://doi. org/10.1002/ijc.2910610222

53. Botzler C, Issels R, Multhoff G (1996) Heat-shock protein 72 cell-surface expression on human lung carcinoma cells in associated with an increased sensitivity to lysis mediated by adherent natural killer cells. Cancer Immunol Immunother 43(4):226-230. https://doi.org/10.1007/s002620050326

54. Dutta SK, Girotra M, Singla M, Dutta A, Otis Stephen F, Nair PP, Merchant NB (2012) Serum HSP70: a novel biomarker for early detection of pancreatic cancer. Pancreas 41(4):530-534. https:// doi.org/10.1097/MPA.0b013e3182374ace

55. Chalmin F, Ladoire S, Mignot G, Vincent J, Bruchard M, RemyMartin JP, Boireau W, Rouleau A, Simon B, Lanneau D, De Thonel A, Multhoff G, Hamman A, Martin F, Chauffert B, Solary E, Zitvogel L, Garrido C, Ryffel B, Borg C, Apetoh L, Rebe C, Ghiringhelli F (2010) Membrane-associated Hsp72 from tumorderived exosomes mediates STAT3-dependent immunosuppressive function of mouse and human myeloid-derived suppressor cells. J Clin Investig 120(2):457-471. https://doi.org/10.1172/ JCI40483

56. Multhoff G (2007) Heat shock protein 70 (Hsp70): membrane location, export and immunological relevance. Methods 43(3):229-237. https://doi.org/10.1016/j.ymeth.2007.06.006

57. Gobbo J, Marcion G, Cordonnier M, Dias AMM, Pernet N, Hammann A, Richaud S, Mjahed H, Isambert N, Clausse V, Rebe C, Bertaut A, Goussot V, Lirussi F, Ghiringhelli F, de Thonel A, Fumoleau P, Seigneuric R, Garrido C (2016) Restoring anticancer immune response by targeting tumor-derived exosomes with a HSP70 peptide aptamer. J Natl Cancer Inst. https://doi. org/10.1093/jnci/djv330

58. Murphy ME (2013) The HSP70 family and cancer. Carcinogenesis 34(6):1181-1188. https://doi.org/10.1093/carcin/bgt111

59. Zheng G, Zhang Z, Liu H, Xiong Y, Luo L, Jia X, Peng C, Zhang Q, Li N, Gu Y, Lu M, Song Y, Pan H, Liu J, Liu W, He Z (2018) HSP27-mediated extracellular and intracellular signaling pathways synergistically confer chemoresistance in squamous cell carcinoma of tongue. Clin Cancer Res 24(5):1163-1175. https ://doi.org/10.1158/1078-0432.CCR-17-2619

60. Rui Z, Jian-Guo J, Yuan-Peng T, Hai P, Bing-Gen R (2003) Use of serological proteomic methods to find biomarkers associated with breast cancer. Proteomics 3(4):433-439. https://doi. org/10.1002/pmic.200390058

61. Bausero MA, Page DT, Osinaga E, Asea A (2004) Surface expression of Hsp25 and Hsp72 differentially regulates tumor growth and metastasis. Tumour Biol 25(5-6):243-251. https:// doi.org/10.1159/000081387

62. Feng JT, Liu YK, Song HY, Dai Z, Qin LX, Almofti MR, Fang CY, Lu HJ, Yang PY, Tang ZY (2005) Heat-shock protein 27: a potential biomarker for hepatocellular carcinoma identified by serum proteome analysis. Proteomics 5(17):4581-4588. https:// doi.org/10.1002/pmic.200401309

63. Olejek A, Damasiewicz-Bodzek A, Bodzek P, Wielkoszynski T, Zamlynski J, Stoltny P, Skutil M (2009) Concentrations of antibodies against heat shock protein 27 in the sera of women with ovarian carcinoma. Int J Gynecol Cancer 19(9):1516-1520. https://doi.org/10.1111/IGC.0b013e3181bf425b

64. Zhao M, Ding JX, Zeng K, Zhao J, Shen F, Yin YX, Chen Q (2014) Heat shock protein 27: a potential biomarker of peritoneal metastasis in epithelial ovarian cancer? Tumour Biol 35(2):1051-1056. https://doi.org/10.1007/s13277-013-1139-7

65. Sims JD, McCready J, Jay DG (2011) Extracellular heat shock protein (Hsp)70 and Hsp90alpha assist in matrix metalloproteinase- 2 activation and breast cancer cell migration and invasion. PLoS ONE 6(4):e18848. https://doi.org/10.1371/journ al.pone. 0018848

66. McCready J, Wong DS, Burlison JA, Ying W, Jay DG (2014) An impermeant ganetespib analog inhibits extracellular Hsp90mediated cancer cell migration that involves lysyl oxidase 2-like protein. Cancers 6(2):1031-1046. https://doi.org/10.3390/cance rs6021031

67. McCready J, Sims JD, Chan D, Jay DG (2010) Secretion of extracellular hsp90alpha via exosomes increases cancer cell motility: a role for plasminogen activation. BMC Cancer 10:294. https:// doi.org/10.1186/1471-2407-10-294 
68. Eustace BK, Sakurai T, Stewart JK, Yimlamai D, Unger C, Zehetmeier C, Lain B, Torella C, Henning SW, Beste G, Scroggins BT, Neckers L, Ilag LL, Jay DG (2004) Functional proteomic screens reveal an essential extracellular role for hsp90 alpha in cancer cell invasiveness. Nat Cell Biol 6(6):507-514. https://doi.org/10.1038/ncb1131

69. Hunter MC, O’Hagan KL, Kenyon A, Dhanani KC, Prinsloo E, Edkins AL (2014) Hsp90 binds directly to fibronectin (FN) and inhibition reduces the extracellular fibronectin matrix in breast cancer cells. PLoS ONE 9(1):e86842. https://doi.org/10.1371/ journal.pone.0086842

70. Walker C, Mojares E, Del Rio HA (2018) Role of extracellular matrix in development and cancer progression. Int J Mol Sci. https://doi.org/10.3390/ijms19103028

71. Bonnans C, Chou J, Werb Z (2014) Remodelling the extracellular matrix in development and disease. Nat Rev Mol Cell Biol 15(12):786-801. https://doi.org/10.1038/nrm3904

72. Gkretsi V, Stylianopoulos T (2018) Cell adhesion and matrix stiffness: coordinating cancer cell invasion and metastasis. Front Oncol 8:145. https://doi.org/10.3389/fonc.2018.00145

73. Egeblad M, Werb Z (2002) New functions for the matrix metalloproteinases in cancer progression. Nat Rev Cancer 2(3):161-174. https://doi.org/10.1038/nrc745

74. Mook OR, Frederiks WM, Van Noorden CJ (2004) The role of gelatinases in colorectal cancer progression and metastasis. Biochem Biophys Acta 1705(2):69-89. https://doi.org/10.1016/j. bbcan.2004.09.006

75. Kessenbrock K, Plaks V, Werb Z (2010) Matrix metalloproteinases: regulators of the tumor microenvironment. Cell 141(1):5267. https://doi.org/10.1016/j.cell.2010.03.015

76. Barker HE, Cox TR, Erler JT (2012) The rationale for targeting the LOX family in cancer. Nat Rev Cancer 12(8):540-552. https ://doi.org/10.1038/nrc3319

77. De Maio A (2011) Extracellular heat shock proteins, cellular export vesicles, and the Stress Observation System: a form of communication during injury, infection, and cell damage. It is never known how far a controversial finding will go! Dedicated to Ferruccio Ritossa. Cell Stress Chaperones 16(3):235-249. https://doi.org/10.1007/s12192-010-0236-4

78. Binder RJ, Vatner R, Srivastava P (2004) The heat-shock protein receptors: some answers and more questions. Tissue Antigens 64(4):442-451. https://doi.org/10.1111/j.1399-0039.2004.00299 . $\mathrm{x}$

79. Murshid A, Theriault J, Gong J, Calderwood SK (2011) Investigating receptors for extracellular heat shock proteins. Methods Mol Biol 787:289-302. https://doi.org/10.1007/978-1-61779 $-295-3 \_22$

80. Moestrup SK, Gliemann J, Pallesen G (1992) Distribution of the alpha 2-macroglobulin receptor/low density lipoprotein receptorrelated protein in human tissues. Cell Tissue Res 269(3):375382. https://doi.org/10.1007/bf00353892

81. Herz J, Strickland DK (2001) LRP: a multifunctional scavenger and signaling receptor. J Clin Investig 108(6):779-784. https:// doi.org/10.1172/JCI13992

82. von Arnim CA, Kinoshita A, Peltan ID, Tangredi MM, Herl L, Lee BM, Spoelgen R, Hshieh TT, Ranganathan S, Battey FD, Liu CX, Bacskai BJ, Sever S, Irizarry MC, Strickland DK, Hyman BT (2005) The low density lipoprotein receptor-related protein (LRP) is a novel beta-secretase (BACE1) substrate. J Biol Chem 280(18):17777-17785. https://doi.org/10.1074/jbc.M414248200

83. Langlois B, Perrot G, Schneider C, Henriet P, Emonard H, Martiny L, Dedieu S (2010) LRP-1 promotes cancer cell invasion by supporting ERK and inhibiting JNK signaling pathways. PLoS ONE 5(7):e11584. https://doi.org/10.1371/journal.pone.0011584
84. Emonard H, Theret L, Bennasroune AH, Dedieu S (2014) Regulation of LRP-1 expression: make the point. Pathol Biol 62(2):84-90. https://doi.org/10.1016/j.patbio.2014.02.002

85. Xing P, Liao Z, Ren Z, Zhao J, Song F, Wang G, Chen K, Yang J (2016) Roles of low-density lipoprotein receptor-related protein 1 in tumors. Chin J Cancer 35:6. https://doi.org/10.1186/s4088 0-015-0064-0

86. Basu S, Binder RJ, Ramalingam T, Srivastava PK (2001) CD91 is a common receptor for heat shock proteins gp96, hsp90, hsp70, and calreticulin. Immunity 14(3):303-313. https://doi. org/10.1016/s1074-7613(01)00111-x

87. Takeda K, Kaisho T, Akira S (2003) Toll-like receptors. Annu Rev Immunol 21:335-376. https://doi.org/10.1146/annur ev.immunol.21.120601.141126

88. Pradere JP, Dapito DH, Schwabe RF (2014) The Yin and Yang of Toll-like receptors in cancer. Oncogene 33(27):3485-3495. https://doi.org/10.1038/onc.2013.302

89. Fukui R, Murakami Y, Miyake K (2018) New application of anti-TLR monoclonal antibodies: detection, inhibition and protection. Inflamm Regener 38:11. https://doi.org/10.1186/s4123 2-018-0068-7

90. Hynes NE, Lane HA (2005) ERBB receptors and cancer: the complexity of targeted inhibitors. Nat Rev Cancer 5(5):341354. https://doi.org/10.1038/nrc1609

91. Vonderheide RH (2020) CD40 agonist antibodies in cancer immunotherapy. Annu Rev Med 71:47-58. https://doi. org/10.1146/annurev-med-062518-045435

92. Elgueta R, Benson MJ, de Vries VC, Wasiuk A, Guo Y, Noelle RJ (2009) Molecular mechanism and function of CD40/CD40L engagement in the immune system. Immunol Rev 229(1):152172. https://doi.org/10.1111/j.1600-065X.2009.00782.x

93. Liu X, Yan Z, Huang L, Guo M, Zhang Z, Guo C (2011) Cell surface heat shock protein 90 modulates prostate cancer cell adhesion and invasion through the integrin-beta1/focal adhesion kinase/c-Src signaling pathway. Oncol Rep 25(5):13431351. https://doi.org/10.3892/or.2011.1202

94. Yi Z, Li Y, Liu D, Liu J, Li H (2017) Extracellular HSP70/ HSP70-PCs regulate hepatocarcinoma cell migration and invasion via RhoA. Oncol Lett 13(3):1095-1100. https://doi. org/10.3892/ol.2016.5551

95. Paz H, Pathak N, Yang J (2014) Invading one step at a time: the role of invadopodia in tumor metastasis. Oncogene 33(33):4193-4202. https://doi.org/10.1038/onc.2013.393

96. Boel NM, Hunter MC, Edkins AL (2018) LRP1 is required for novobiocin-mediated fibronectin turnover. Sci Rep 8(1):11438. https://doi.org/10.1038/s41598-018-29531-2

97. Chakraborty A, Boel NM, Edkins AL (2020) HSP90 interacts with the fibronectin N-terminal domains and increases matrix formation. Cells. https://doi.org/10.3390/cells9020272

98. Ouyang G, Wang Z, Fang X, Liu J, Yang CJ (2010) Molecular signaling of the epithelial to mesenchymal transition in generating and maintaining cancer stem cells. Cell Mol Life Sci 67(15):2605-2618. https://doi.org/10.1007/s00018-010-0338-2

99. Hance MW, Dole K, Gopal U, Bohonowych JE, JezierskaDrutel A, Neumann CA, Liu H, Garraway IP, Isaacs JS (2012) Secreted Hsp90 is a novel regulator of the epithelial to mesenchymal transition (EMT) in prostate cancer. J Biol Chem 287(45):37732-37744. https://doi.org/10.1074/jbc. M112.389015

100. Nolan KD, Franco OE, Hance MW, Hayward SW, Isaacs JS (2015) Tumor-secreted Hsp90 subverts polycomb function to drive prostate tumor growth and invasion. J Biol Chem 290(13):8271-8282. https://doi.org/10.1074/jbc.M115.637496

101. Nolan KD, Kaur J, Isaacs JS (2017) Secreted heat shock protein 90 promotes prostate cancer stem cell heterogeneity. Oncotarget 8(12):19323-19341. https://doi.org/10.18632/oncotarget.14252 
102. Chen WS, Chen CC, Chen LL, Lee CC, Huang TS (2013) Secreted heat shock protein 90alpha (HSP90alpha) induces nuclear factor-kappaB-mediated TCF12 protein expression to down-regulate E-cadherin and to enhance colorectal cancer cell migration and invasion. J Biol Chem 288(13):9001-9010. https ://doi.org/10.1074/jbc.M112.437897

103. Li H, Li Y, Liu D, Sun H, Su D, Yang F, Liu J (2013) Extracellular HSP70/HSP70-PCs promote epithelial-mesenchymal transition of hepatocarcinoma cells. PLoS ONE 8(12):e84759. https:// doi.org/10.1371/journal.pone.0084759

104. Radisky ES, Radisky DC (2010) Matrix metalloproteinaseinduced epithelial-mesenchymal transition in breast cancer. $\mathrm{J}$ Mammary Gland Biol Neoplasia 15(2):201-212. https://doi. org/10.1007/s10911-010-9177-x

105. Dong H, Zou M, Bhatia A, Jayaprakash P, Hofman F, Ying Q, Chen M, Woodley DT, Li W (2016) Breast cancer MDA-MB-231 cells use secreted heat shock protein-90alpha (Hsp90alpha) to survive a hostile hypoxic environment. Sci Rep 6:20605. https:// doi.org/10.1038/srep20605

106. Gopal U, Bohonowych JE, Lema-Tome C, Liu A, Garrett-Mayer E, Wang B, Isaacs JS (2011) A novel extracellular Hsp90 mediated co-receptor function for LRP1 regulates EphA2 dependent glioblastoma cell invasion. PLoS ONE 6(3):e17649. https://doi. org/10.1371/journal.pone.0017649

107. Gehrmann M, Marienhagen J, Eichholtz-Wirth H, Fritz E, Ellwart J, Jäättelä M, Zilch T, Multhoff G (2005) Dual function of membrane-bound heat shock protein 70 (Hsp70), Bag-4, and Hsp40: protection against radiation-induced effects and target structure for natural killer cells. Cell Death Differ 12(1):38-51. https://doi.org/10.1038/sj.cdd.4401510

108. Wu FH, Yuan Y, Li D, Liao SJ, Yan B, Wei JJ, Zhou YH, Zhu JH, Zhang GM, Feng ZH (2012) Extracellular HSPA1A promotes the growth of hepatocarcinoma by augmenting tumor cell proliferation and apoptosis-resistance. Cancer Lett 317(2):157-164. https ://doi.org/10.1016/j.canlet.2011.11.020

109. Sidera K, Gaitanou M, Stellas D, Matsas R, Patsavoudi E (2008) A critical role for HSP90 in cancer cell invasion involves interaction with the extracellular domain of HER-2. J Biol Chem 283(4):2031-2041. https://doi.org/10.1074/jbc.M701803200

110. El Hamidieh A, Grammatikakis N, Patsavoudi E (2012) Cell surface Cdc37 participates in extracellular HSP90 mediated cancer cell invasion. PLoS ONE 7(8):e42722. https://doi.org/10.1371/ journal.pone.0042722

111. Stellas D, Karameris A, Patsavoudi E (2007) Monoclonal antibody 4C5 immunostains human melanomas and inhibits melanoma cell invasion and metastasis. Clin Cancer Res 13(6):18311838. https://doi.org/10.1158/1078-0432.CCR-06-1585

112. Thuringer D, Hammann A, Benikhlef N, Fourmaux E, Bouchot A, Wettstein G, Solary E, Garrido C (2011) Transactivation of the epidermal growth factor receptor by heat shock protein 90 via Toll-like receptor 4 contributes to the migration of glioblastoma cells. J Biol Chem 286(5):3418-3428. https://doi.org/10.1074/ jbc.M110.154823

113. de la Mare JA, Jurgens T, Edkins AL (2017) Extracellular Hsp90 and TGFbeta regulate adhesion, migration and anchorage independent growth in a paired colon cancer cell line model. BMC Cancer 17(1):202. https://doi.org/10.1186/s12885-017-3190-z

114. Somensi N, Brum PO, de Miranda RV, Gasparotto J, ZanottoFilho A, Rostirolla DC, da Silva MM, Moreira JCF, Pens Gelain D (2017) Extracellular HSP70 activates ERK1/2, NF-kB and pro-inflammatory gene transcription through binding with RAGE in A549 human lung cancer cells. Cell Physiol Biochem 42(6):2507-2522. https://doi.org/10.1159/000480213

115. Tsuneki M, Maruyama S, Yamazaki M, Xu B, Essa A, Abe T, Babkair H, Cheng J, Yamamoto T, Saku T (2013) Extracellular heat shock protein A9 is a novel interaction partner of podoplanin in oral squamous cell carcinoma cells. Biochem Biophys Res Commun 434(1):124-130. https://doi.org/10.1016/j. bbrc.2013.03.057

116. De Palma M, Biziato D, Petrova TV (2017) Microenvironmental regulation of tumour angiogenesis. Nat Rev Cancer 17(8):457474. https://doi.org/10.1038/nrc.2017.51

117. Song X, Wang X, Zhuo W, Shi H, Feng D, Sun Y, Liang Y, Fu Y, Zhou D, Luo Y (2010) The regulatory mechanism of extracellular Hsp90\{alpha\} on matrix metalloproteinase-2 processing and tumor angiogenesis. J Biol Chem 285(51):40039-40049. https ://doi.org/10.1074/jbc.M110.181941

118. Kern J, Untergasser G, Zenzmaier C, Sarg B, Gastl G, Gunsilius E, Steurer M (2009) GRP-78 secreted by tumor cells blocks the antiangiogenic activity of bortezomib. Blood 114(18):39603967. https://doi.org/10.1182/blood-2009-03-209668

119. Thuringer D, Jego G, Wettstein G, Terrier O, Cronier L, Yousfi N, Hebrard S, Bouchot A, Hazoume A, Joly AL, Gleave M, RosaCalatrava M, Solary E, Garrido C (2013) Extracellular HSP27 mediates angiogenesis through Toll-like receptor 3. FASEB J 27(10):4169-4183. https://doi.org/10.1096/fj.12-226977

120. Bohonowych JE, Hance MW, Nolan KD, Defee M, Parsons CH, Isaacs JS (2014) Extracellular Hsp90 mediates an NF-kappaB dependent inflammatory stromal program: implications for the prostate tumor microenvironment. Prostate 74(4):395-407. https ://doi.org/10.1002/pros.22761

121. Chen CC, Chen LL, Li CP, Hsu YT, Jiang SS, Fan CS, Chua KV, Huang SX, Shyr YM, Chen LT, Huang TS (2018) Myeloidderived macrophages and secreted HSP90alpha induce pancreatic ductal adenocarcinoma development. Oncoimmunology 7(5):e1424612. https://doi.org/10.1080/2162402X.2018.14246 12

122. Kaczmarek M, Lagiedo M, Masztalerz A, Kozlowska M, Nowicka A, Brajer B, Batura-Gabryel H, Sikora J (2018) Concentrations of SP-A and HSP70 are associated with polarization of macrophages in pleural effusions of non-small cell lung cancer. Immunobiology 223(2):200-209. https://doi.org/10.1016/j. imbio.2017.10.025

123. Berthenet K, Boudesco C, Collura A, Svrcek M, Richaud S, Hammann A, Causse S, Yousfi N, Wanherdrick K, Duplomb L, Duval A, Garrido C, Jego G (2016) Extracellular HSP110 skews macrophage polarization in colorectal cancer. Oncoimmunology 5(7):e1170264. https://doi.org/10.1080/2162402X.2016.1170264

124. Banerjee S, Lin CF, Skinner KA, Schiffhauer LM, Peacock J, Hicks DG, Redmond EM, Morrow D, Huston A, Shayne M, Langstein HN, Miller-Graziano CL, Strickland J, O’Donoghue L, De AK (2011) Heat shock protein 27 differentiates tolerogenic macrophages that may support human breast cancer progression. Can Res 71(2):318-327. https://doi.org/10.1158/0008-5472. CAN-10-1778

125. Chen YQ, Li PC, Pan N, Gao R, Wen ZF, Zhang TY, Huang F, Wu FY, Ou XL, Zhang JP, Zhu XJ, Hu HM, Chen K, Cai YL, Wang LX (2019) Tumor-released autophagosomes induces CD4(+) T cell-mediated immunosuppression via a TLR2-IL-6 cascade. J Immunother Cancer 7(1):178. https://doi.org/10.1186/ s40425-019-0646-5

126. Rerole AL, Gobbo J, De Thonel A, Schmitt E, Pais de Barros JP, Hammann A, Lanneau D, Fourmaux E, Demidov ON, Micheau O, Lagrost L, Colas P, Kroemer G, Garrido C (2011) Peptides and aptamers targeting HSP70: a novel approach for anticancer chemotherapy. Can Res 71(2):484-495. https://doi. org/10.1158/0008-5472.CAN-10-1443

127. Workman P, Burrows F, Neckers L, Rosen N (2007) Drugging the cancer chaperone HSP90: combinatorial therapeutic exploitation of oncogene addiction and tumor stress. Ann N Y Acad Sci 1113:202-216. https://doi.org/10.1196/annals.1391.012 
128. Tsutsumi S, Scroggins B, Koga F, Lee MJ, Trepel J, Felts S, Carreras C, Neckers L (2008) A small molecule cell-impermeant Hsp90 antagonist inhibits tumor cell motility and invasion. Oncogene 27(17):2478-2487. https://doi.org/10.1038/sj.onc.1210897

129. Weng D, Song B, Koido S, Calderwood SK, Gong J (2013) Immunotherapy of radioresistant mammary tumors with early metastasis using molecular chaperone vaccines combined with ionizing radiation. J Immunol 191(2):755-763. https://doi. org/10.4049/jimmunol.1203286
130. Murshid A, Gong J, Calderwood SK (2012) The role of heat shock proteins in antigen cross presentation. Front Immunol 3:63. https://doi.org/10.3389/fimmu.2012.00063

Publisher's Note Springer Nature remains neutral with regard to jurisdictional claims in published maps and institutional affiliations. 